УДК: 371.3::821.163.41

821.163.41.09-342 Олујић Г. https://doi.org/10.18485/kij.2017.64.1_2.17

\author{
АНА Д. КОЗИЪ ${ }^{*}$ \\ Универзитет у Београду \\ Филолошки факултет, мастер студије
}

Оригинални научни рад

Примљен: 27.02.2017.

Прихваћен: 15.04.2017.

\title{
АУТОРСКЕ БАЈКЕ ГРОЗДАНЕ ОЛУЈИЋ У НАСТАВИ
}

\begin{abstract}
У раду се разматрају различите могућности тумачења ауторских бајки Гроздане Олујић у основној школи. Посебна пажња посвећена је ваљаним методичким радњама којима се ученици подстичу да свестрано тумаче идејно и уметничко богатство дела. На примеру бајки Седефна ружа, Небеска река и Звезда у чијим је грудима нешто куиало указује се на одговарајуће методичке поступке који су вишеструко мотивисани и повезани са наставним циљевима. У раду се сагледавају и могућности упоредног тумачења одлика народне и ауторске бајке на примеру бајки Гроздане Олујић.
\end{abstract}

Кључне речи: Гроздана Олујић, ауторска бајка, настава, народна бајка, наставни циљеви, интерпретација.

Књижевно дело Гроздане Олујић заступљено је у основној школи са три бајке и једним романом - Небеска река обрађује се у петом разреду, Седефна ружа у шестом, Звезда у чијим је грудима нешто куцало у седмом, а у осмом разреду програмом је предвиђен роман Гласам за љубав. Наведене бајке својом тематиком, структуром, ликовима и неочекиваним завршецима представљају једна од омиљених дела за читање и тумачење у настави. ${ }^{1}$ Проучавање бајки Гроздане Олујић у основној школи развија ученичку машту, способност апс-

*ana.kozic@hotmail.com

${ }^{1} \mathrm{O}$ популарности овог жанра сведочи и то што у последњих неколико година бајке, ауторске и народне, доживљавају обнову на филму и у серијама. Оно што се у овим екранизацијама истиче то је нови поглед на негативне јунаке, па се тако проблематизују поступци злих јунака и указује се да оно што се на први поглед чини као зло у ствари дела из патње и повређености (филм Maleficent) или страха (анимирани филм Frozen). Оваква подвојеност одувек је била присутна у бајкама и њен значај за развој детета често је истицан: „Насупрот ономе што се збива у многим модерним причама за децу, у бајкама је зло свуда присутно, баш као и врлина. У скоро свакој бајци, добро и зло су оваплоћени у виду извесних ликова и њихових поступака, као што су добро и зло свеприсутни у животу а склоности и ка једном и ка другом присутне у сваком човеку. То двојство свакако поставља морални проблем и изискује напоре за његово решавање” (Бетелхајм 1979: 23). 
трактног мишљења и чулну имагинацију ученика, а својом лепотом, тематиком и високим уметничким вредностима ове ауторске бајке могу подстаћи ученике и на креативно изражавање. Ученици воле да читају бајке и да разговарају о њима, па тако у уводном делу часа наставник може водити припремни разговор са ученицима. Функција овог разговора је у мотивисању за што потпуније слушање, читање и тумачење књижевноуметничког текста. Наставник позива ученике да се присете бајки које су раније читали, а то обраћање може изгледати овако:

- Која је ваша омиљена бајка? - Зашто вам је баш та бајка омиљена? - Чиме нас све бајке привлаче? - Какви су јунаци приказани у бајкама? - Зашто нам је лако да се са њима поистоветимо?

Ученици ће издвајати оне бајке које су им најпознатије и најдраже, а међу њима ће се сигурно наћи „Снежана и седам патуљака”, „Мала сирена”, „Успавана лепотица”, „Пепељуга”, „Мачак у чизмама” и друге бајке у верзијама браће Грим и Х. К. Андерсена, а претпоставља се да ће ученици наводити и наше народне бајке које су им познате из школског програма. Овом приликом ученици ће издвојити ликове бајки и истицати њихову упорност у остварењу својих циљева. Ту особину јунака бајки наставник може повезати са главним јунакињама бајки Гроздане Олујић, смештајући на тај начин њено дело у контекст савремене књижевности и дуге традиције приповедања, писања, читања и тумачења бајки. ${ }^{2}$ Ово се може постићи и информисањем ученика о бројним домаћим и светским признањима које је Гроздана Олујић добила за свој књижевни рад. Њене ауторске бајке су изузетно популарне - бајке из збирке Седефна ружа адаптиране су као телевизијска серија у девет епизода, постоји и плоча Седефна ружа у интерпретацији Мије Алексића, а у позоришту Ег у Олбенију (Њујорк) Грозданине бајке постављене су и као мјузикл. Поред тога Гроздана Олујић је добила низ националних и интернационалних признања, ${ }^{3}$ између осталог и витешки орден Данеборг Данске за заслуге у књижевности, па се ученици могу подстаћи да ову награду повежу са традицијом бајки у Данској и остварењима Ханса Кристијана Андерсена, чије дело је утицало и на стваралаштво Гроздане Олујић. Овакве информације могу ученицима бити занимљиве и подстицајне и могу послужити као мотивација за пажљиво слушање изражајног читања бајке. Овим поводом наставник се ученицима може обратити на следећи начин:

${ }^{2}$ Ауторска бајка намењена деци у српској књижевности појављује се тридесетих година XX века, прво кроз преводе и адаптације, а потом и кроз оригинална дела (Опачић 2011: 39). Зорана Опачић истиче да је преиначавање фолклорног наслеђа остало трајна карактеристика српске ауторске бајке, па се у том смислу могу издвојити два модела - у првом доминира транспозиција епског наслеђа и народне традиције у бајку (Даница Бандић, Десанка Максимовић, Бранко Ћопић), док се у другом јавља ауторска бајка као парабола по угледу на бајке Андерсена и Вајлда и постаје прича о антропоморфизованим предметима и бићима природе као у делима Стевана Раичковића, Бранка В. Радичевића и Гроздане Олујић (Исто: 40). У овим бајкама крај представља смрт или метаморфозу јунака чиме судбина тог јунака постаје парабола о животу појединца у савремености (Исто: 40)

${ }^{3}$ Награда Политикиног забавника, Младог поколења, награда Змајевих дечјих игара 1990, награда World Academy for Art and Culture 1994, Повеља за животно дело Змајевих дечјих игара 2001, Златни лептир 2001, Повеља Стара маслина 2001, Повеља УКС за животно дело 2004. 
Предмет нашег данашњег разговора биће дело Гроздане Олујић, „Седефна ружа”. Гроздана Олујић је наш савремени писац за децу и одрасле. Њена дела преведена су на двадесет и осам језика и доживела су чак и извођење у светским позориштима, па је тако збирка бајки Седефна ружа преточена у мјузикл у позоришту Ег у Њујорку. Поред тога, Гроздана Олујић је добитница и бројних књижевних награда, а између осталог, носилац је данског витешког ордена из реда Данеброг и почасни је грађанин града Осла. Којег данског писца бајки познајете? Које су његове најпознатије бајке? У делу Ханса Кристијана Андерсена и бајкама Гроздане Олујић има доста сличности. У вашим читанкама налази се једна од њених најлепших бајки, „Седефна ружа”. Пажљиво слушајте читање бајке и уживите се у свет дела. Током слушања размишљајте о осећањима која се у вама буде и припремите се да говорите о својим утисцима и размишљањима.

Ученици саосећају са главним јунакињама бајки Небеска река, Седефна Ружа и Звезда у чијим је грудима нешто куцало, а њихову усмереност ка остварењу свог циља и превазилажењу препрека повезују са ситуацијама из живота или из личног искуства.

Приликом обраде ауторских бајки Гроздане Олујић у настави се остварује низ естетских, образовних, функционалних и васпитних циљева. Уживљавајући се у уметнички свет ових бајки ученици истичу значај сна, сањарења и маште у животу сваког човека и подстичу се на размишљање о томе да ли је оно што је задато као добро и корисно довољно да нас учини срећним. Читајући Небеску реку, Седефну ружу или Звезду у чијим је грудима нешто куцало открива се да треба слушати и уважавати старије, али да им се не треба увек и слепо повиновати. Истиче се да сваки човек тражи свој пут и своје место у свету и да је значај слободног избора у животу неизрецив, чак и кад се тај избор чини погрешним. Ученицима се открива да увек треба тежити савладавању свих разлика и препрека у остварењу наших снова и тежњи, као и то да се све препреке уз упорност и преданост могу савладати. ${ }^{4}$

Бајке Гроздане Олујић представљају антропоморфизовани свет природе, у Седефној ружи то је подводни свет, у Небеској реции земаљски простор, а у Звезди у чијим је грудима нешто куцало то је небеска сфера. У сва три предела бића природе приказују се са људским особинама и са устројством које је слично савременом свету људи. Реке у Небеској реци, као и звезде у Звезди у чијим је грудима нешто куцало представљене су са људским емоцијама, стрепњама и радостима. Оне се рађају, настају и имају родитеље са којима понекад долазе у сукоб, док различити становници подводног света у Седефној ружи обављају своје свакодневне задатке и послове. Из тог уређеног света издвајају се лико-

${ }^{4}$ „То је управо порука коју бајке у многоструким видовима преносе детету: да је борба против огромних тешкоћа у животу неизбежна, да чини суштински део људског постојања - али да човек, уколико не устукне, већ се непоколебљиво суочава с неочекиваним и често неправедним тегобама, савладава све препреке и на крају излази као победник" (Бетелхајм 1979: 22). Готово идентичан став исказује и Гроздана Олујић у свом теоријском тексту Поетика бајке: „Помажући детету да одрасте, да уђе у равнотежу са самим собом и светом око себе, превазиђе егзистенцијалну језу и страх пред непознатим, већина бајки чини управо то: открива колико човек може да издржи, колико тога да савлада на путу који је често тежак, замршен па и погибељан, али никада несавладив, никада затворен до краја” (Олујић 1981) 
ви који су обузети чежњом за неоткривеним пространствима и који наилазе на осуђивање свих својих сународника због тога. Звезда из бајке Звезда у чијим је грудима нешто куцало чезне за земљом јер се ту налази вољени чобанин и његова музика, малу реку привлаче планински врхунци, сунце и облаци, тј. привлаче је висине и узбудљиви простори, она је светла и прозрачна - у њој се огледа небо за којим жуди. Седефна ружа, такође, машта о горњем свету пуном неизрецивих лепота, а дечак који слуша шум шкољке машта о морским таласима - човеку је чежња својствена, тешко је бити увек на свом месту и бити тим местом задовољан. Оно што је карактеристично за све ове жеље је то што својом природом угрожавају чак и живот јунакиња - с једне стране не могу да се помире са тим да живе у задатим оквирима, а с друге стране излазак из тих оквира представља велику опасност. На то указују и Велика речна мајка и Звездана мајка својим ћеркама. Звездана мајка се боји да ће једног дана њена ћерка изненада бљеснути и у сопственом сјају изгорети, па је зато закључава у небеску башту. Велика речна мајка нуди малој реци да тече на било коју страну света, чиме се истиче да могућност избора постоји, али у одређеним, већ познатим оквирима. Мала река жели да постоји изван тих оквира, а оно што је изван тих граница непознато је и стога застрашујуће. Различита упозорења пружена су и Седефној ружи, од којих је најстрашније упозорење угор рибе да у горњем свету све из морског света чека сигурна смрт у тигању. У том смислу једини срећан крај може се пружити у виду метаморфозе - Седефна ружа ствара бисер као вечни одраз своје чежње, звезда постаје звезда падалица и у незнаним и невиђеним небесима састаје се са чобанином, док се мала река претвара у дугу. ${ }^{5}$ Тада свака кап воде постаје мала призма кроз коју се сунчева светлост прелама и расипа у боје. Од давнина људи су веровали да дуга има магијска својства. У грчкој митологији сматрало се да дуга представља везу између неба и земље, а у Библији након великог потопа, Бог поставља дугу на небо као знак савеза између Бога и људи. Зато се дуга често повезује са надом и променом, постајући симбол мира и савезништва. На тај начин Мала река је захваљујући својој упорности и храбрости успела да се попне до неба и да ту остане као нада и подршка свима који наилазе на препреке у остварењу свог животног пута.

У појединим бајкама Гроздане Олујић присутна је изражена тежња да се победи пролазност и смисао пронађе у уметности (Опачић 2011: 160), а ово се посебно односи на бајку Седефна ружа, али и бајку Звезда у чијим је грудима нешто куиало. Седефна ружа ствара бисер од дуготрајног и снажног бола који узрокује неостварена чежња. Туга се скупља, згушњава и претвара у бисер. Ово се може тумачити и као представа уметничког стварања - бисер, баш као и

${ }^{5}$ Гроздана Олујић истиче: „У својој устремљености унапред, сталном физичком и психичком расту дете наслућује смисао смрти, али је не признаје, као што је ни бајка не признаје. Смрт је у бајци само претапање једног облика у други: оловни војник постаје оловно срце, Мала сирена претвара се у пену која ће се кроз триста година поново претворити у сирену, коначне таме и коначног нестанка - нема! Психолошки и едукативно гледано то је највеће чудо и највећа истина коју нам казује бајка" (Олујић 1981). 
уметничко дело, постаје свет за себе и у себи, и сјаји вечним сјајем, који могу разумети само они који и сами умеју да воле и чезну попут дечака и шкољке. На сличан начин уметност, односно музика постаје спона између чобанина и звезде - она прва привлачи пажњу звезди, а како њихова међусобна љубав расте и музика фруле постаје све лепша, док не очара целокупну природу и учини да се догоде невероватне ствари. Овакав опис умногоме подсећа на Орфеја и моћ његове музике: „Све дуже и нежније је свирао, док није и језеро, и шуму и Месец на небу зачарао. Обамрле и неме слушале су га звезде. Његова, наједном, букну и откиде се с неба. Шта је се тиче небо! До ђавола и вечност!” (Олујић 1979: 171). Љубав коју звезда осећа према чобанину као и лепота његове музике представљају нешто што вреди више и од саме вечности. Њихов сусрет и срећа у неком неисказаном небу наговештени су кроз опојну музику фруле која још увек траје и коју могу разумети и чути само они који и сами воле.

Приликом тумачења бајки Гроздане Олујић у настави треба указати ученицима и на високе уметничке квалитете ових дела. Не треба заборавити да се говори о ауторском делу које не само својом темом већ и стилом и језиком проналази свој пут до читаоца. ${ }^{6}$ Ауторске бајке Гроздане Олујић одликује препознатљив стилски и језички израз, тако да ученике треба подстицати да препознају својеврсну експресивност и набој емоција који се исказује бројним упитним и узвичним реченицама („Како је тиха, како глатка била површина воде! Како блиставе и нежне гране врба, врхови трава, лет свица" (Исто:167) - Звезда у чијим је грудима нешто куцало), затим ту је карактеристична промена уобичајеног редоследа речи у реченици чиме се истиче финална позиција појединих речи (,Дубоко на дну мора, где зраци сунца стижу тек у подне, живела је шкољка лепотица, звана Седефна ружа" (Исто:7) - Седефна ружа), а ту су и својеврсна поређења која доприносе уметничкој вредности дела, чинећи њену прозу лирском и поетском („Али, у светле летње вечери када се у језеру, као бели цветови локвања, расцветају звезде (...)" (Исто:172) - Звезда у чијим је грудима нешто куцзало; „као сребрне стреле летела су јата риба” (Исто: 10) - Седефна ружа). Вођени подстицајима наставника на часу или преко захтева за истраживачко читање ученици препознају и тумаче стилско-језичку компоненту бајки Гроздане Олујић, истичући на тај начин уметничке квалитете дела. Ево како би један од истраживачких задатака, који би се бавио језичко-стилском компонентом бајке Седефна ружа, могао да изгледа:

Прочитајте још једном следећи одломак из бајке Седефна ружа, који описује прижељкивани сусрет шкољке са Горњим светом: „Као златна вртешка окретало је Сунце небо, гонили се облаци лакши од морске пене, растао слани дах мора и слатки мирис рузмариновог цвета. Како је све бљештало, све трептало блиставије и нежније но што је риба запамтила!" Каквом чулном утиску доприноси овакав опис? Објасни чиме се постиже експресивност у

\footnotetext{
${ }^{6}$ „Уживање које доживљавамо када себи допустимо да реагујемо на бајку, опчињеност коју осећамо, не потичу од психолошког значења приче (мада и оно доприноси), већ од њених литерарних квалитета - од саме приче као уметничког дела. Бајка не би могла имати своје психолошко дејство на дете да није најпре и изнад свега - уметничко дело" (Бетелхајм 1979: 26-27).
} 
опису. Које стилске фигуре препознајеш? Образложи њихову функцију. Пронађи у тексту бајке слична места и образлажи њихову лепоту и вредност. Издвој места која су за тебе била најупечатљивија и образложи свој одговор.

Бајке Гроздане Олујић могу бити подстицајне и за креативно стварање не само оним што приказују и описују већ и оним што прећуткују. У том смислу ученицима петог разреда може бити занимљиво то што у бајци Небеска река не постоји конкретан опис пењања мале реке на небо. Свакако да овакво изостављање није случајно и да пружа слободу читаоцима да домаштају сопствену верзију догађаја. Уколико ученици покажу интересовање за ову тему може им се као домаћи задатак дати да опишу како се мала река попела на небо, јер се на тај начин подстиче њихова креативност и негује култура писаног изражавања.

Наставна обрада бајки Гроздане Олујић може бити и прилика да ученици обнове знања о народној књижевности и народним бајкама, као и да се још једном ученицима укаже на разлике између народне и ауторске књижевности. Прво се ученицима може указати на место бајке као жанра у подели на родове и врсте у ауторској и народној књижевности. Народна књижевност дели се на поезију, прозу и кратке усмене облике, док драме нема (иако постоје њени рудиментни остаци у неким народним песмама), а у оквиру прозе разликују се две категорије - приповетке и предања, за разлику од ауторске књижевности где приповетке представљају врсту у оквиру епике (Мркаљ 2011: 88). ${ }^{7}$ У народној књижевности под категорију приповетке спадају: бајке, басне, приче о животињама, шаљиве приче, новеле, анегдоте, ратничко-патријархалне анегдоте и легендарне приче (Исто: 88), па је тако и народна бајка по својој категорији приповетка, док је ауторска бајка врста у оквиру књижевног рода епике.

Поред класификације, ученицима треба указати на сличности и разлике између усмене и ауторске бајке. Код тумачења народних бајки у настави намећу се многа питања која се пре свега тичу проблема који се могу појавити приликом истицања теоријских и жанровских одлика бајке (Мркаљ 2008: 223). Присутна је опасност од наметања теоријских одлика једног жанра, које би се потом тражиле и препознавале у тексту, јер се на тај начин ученицима онемогућује да уметнички доживе народну прозу (Исто: 165$).{ }^{8}$ Да би се све то избегло народне бајке треба тумачити са неколико различитих аспеката - са књижевног, перцепцијског, фолклорног и психолошког (Исто: 223-224). Приликом разговора о ауторским бајкама Гроздане Олујић ученици се могу подсетити жанровске структуре народне бајке. Овом приликом они се подстичу да теоријска знања о бајци

${ }^{7}$ Више о проблемима у тумачењу народне књижевности у настави у: Мркаљ, Зона. Наставно проучавање народних приповедака и предања. Београд: Друштво за српски језик и књижевност Србије, 2008 и Мркаљ, Зона. На часовима српског језика и къижевности. Београд: Завод за уџбенике, 2011, 87-102

${ }^{8}$ „Читав корпус питања којима се наставник може послужити да мотивише ученике за читање народних бајки тако бива обесмишљен, а ученик се уместо у позицију поузданог тумача ставља на место одакле препознаје и уочава, али није у погодној прилици да образлаже, повезује и расправља, јер је све већ унапред теоријски назначено и 'прописано”' (Мркаљ 2008: 165) 
конкретизују и илуструју адекватним примерима из бајке Гроздане Олујић која је предмет обраде. Значајно је да ти подстицаји дођу након тумачења мотива, теме, ликова, композиције и језичко-стилског слоја бајке, зато што само ако су теоријски закључци смислено изведени из тумачења дела и илустровани адекватним примерима, они се могу потпуно разумети и усвојити. Ти подстицаји могу овако изгледати:

- Зашто смо Седефну ружу одредили као бајку? - Присетите се неких народних бајки. Које су сличности и разлике између ове (ауторске) бајке и народне бајке? - Какви су јунаци народних бајки, а каква је јунакиња бајке Седефна ружа? - На који начин су представљени време и простор у народним бајкама, а како је то учињено у бајци Гроздане Олујић? - Каква је радња у народним бајкама, а каква у Седефној ружи? - Какав је крај ове приче?

Ученици ће истицати присуство фантастике у избору ликова (персонификоване реке, звезде или морски свет) и тематике бајки Седефна ружа, Небеска река и Звезда у чијим је грудима нешто куцало, одређујући ову особину као једну од главних одлика бајке. Уочиће, такође, да су главне јунакиње ових бајки сличне јунацима из народних бајки у свом настојању да упркос свим препрекама достигну свој циљ, али за разлику од јунака у народним бајкама овде је присутна дубља психолошка карактеризација и богат унутрашњи свет јунака. Поред тога, у народним бајкама главни јунаци су готово увек људи, или евентуално људи који су некаквом магијом претворени у биљке, животиње или предмете, док су у бајкама Гроздане Олујић јунаци бића природе са људским особинама. Време одигравања радње неодређено је као и у народним бајкама, али устројство света и односи међу ликовима у бајкама Гроздане Олујић упућују на савремени људски свет - приказују се сукоби деце са родитељима, свакодневни послови и задаци, надметање у лепоти и слично. Проток времена је, такође, присутан - за разлику од народних бајки, овде јунаци старе и мењају се. У бајкама Гроздане Олујић кретање главних јунакиња је вертикално (Седефна ружа жели да пређе из морског света на копно, мала река са земље на небо, а звезда из Зведе у чијим је грудима нешто куцало жели да се спусти на земљу), док се у народним бајкама јунаци крећу хоризонтално, по простору и свету у ком се већ налазе. Простор у народним бајкама није конкретизован, повезан је са радњом, а описи простора по коме се јунак креће изузетно су ретки, док је у бајкама Гроздане Олујић детаљно описан свет у коме јунаци живе. У ауторским бајкама нема много конкретних дешавања, све се одиграва у свести и унутрашњости главне јунакиње. У средишту приказивања су њене тежње, поступци, страхови, односи са мајком и са околином. То је, такође, једна од разлика у односу на народне бајке, у којима нема дубљег задирања у унутрашњи живот јунака. Осим тога, радње у народним бајкама су динамичне, пуне препрека, догађаја, дигресија и епизода, док су бајке Гроздане Олујић усмерене превасходно на тежњу главне јунакиње да испуни своју чежњу и сан, па се све креће ка том разрешењу. Сам крај приче је амбивалентан, у извесном смислу и срећан и тужан. У Седефној ружи шкољка је успела да види Горњи свет, али је њена тајна откривена и њено мало чудо у виду бисера одвојено је од ње заувек; звезда и чобанин нестају са овог света и срећу 
се у неким другим небесима о којима се не говори. Овакви крајеви поручују да остварење најинтимнијих тежњи подразумева одрицање и велику патњу и због тога крај није срећан у дословном смислу, као што је то случај у народним бајкама. У складу са тим и уобичајене иницијалне и финалне формуле из народних бајки у овим ауторским бајкама изостају (формуле попут „био једном један” или „једном давно”, као и „живели су срећно до краја живота” нису присутне у тексту). Систематизацију изнетих разлика између народне и ауторске бајке Гроздане Олујић наставник може представити путем табеле коју ће нацртати на табли или у штампаној форми поделити ученицима. Та табела може изгледати овако:

\begin{tabular}{|c|c|}
\hline Народне бајке & $\begin{array}{c}\text { Ауторске бајке Гроздане } \\
\text { Олујић }\end{array}$ \\
\hline $\begin{array}{l}\text { Присуство типичних иницијалних и за- } \\
\text { вршних формула („Био једном један цар } \\
\text { па имао три сина” и „Живели су срећно } \\
\text { до краја живота”) }\end{array}$ & $\begin{array}{l}\text { Одсуство иницијалних и заврш- } \\
\text { них формула („Текле реке, свака } \\
\text { по своме: нека на исток, нека на } \\
\text { запад, нека с планине право у } \\
\text { море. Па и куда би?” - Небеска } \\
\text { река) }\end{array}$ \\
\hline $\begin{array}{l}\text { Главни ликови су људи (или људи пре- } \\
\text { ображени у животиње или биљке неком } \\
\text { чаролијом); главни јунаци се не мењају и } \\
\text { нису дубље психолошки окарактерисани }\end{array}$ & $\begin{array}{l}\text { Главни ликови су бића из природе } \\
\text { (реке, звезде, морски свет) која су } \\
\text { налик људима; присутна је пси- } \\
\text { холошка карактеризација ликова } \\
\text { и богат унутрашњи живот јунака }\end{array}$ \\
\hline $\begin{array}{l}\text { Време је неодређено, далека прошлост; } \\
\text { не описује се посебно проток времена, а } \\
\text { јунаци не старе и не мењају се }\end{array}$ & $\begin{array}{l}\text { Време је неодређено, али уст- } \\
\text { ројство и правила описаног света } \\
\text { подсећају на савременост; време } \\
\text { протиче и јунаци се мењају („Над } \\
\text { језером је, као ветром ношен } \\
\text { лист, летело време. Одлазиле су } \\
\text { на пут дивље патке и враћале се, } \\
\text { опет ишле.”- - Звезда у чијим је } \\
\text { грудима нешто куиало) }\end{array}$ \\
\hline Простор је апстрактан и описи су ретки & $\begin{array}{l}\text { Простор је конкретизован, детаљ- } \\
\text { но описан са утврђеним прави- } \\
\text { лима и становницима („Седефна } \\
\text { ружа саже главу и загледа се у пе- } \\
\text { сак преко којег су клизиле сенке } \\
\text { рибљих јата, а на стени, не већој } \\
\text { од педља, певушила корална гра- } \\
\text { на"- Седефна ружа) }\end{array}$ \\
\hline
\end{tabular}




\begin{tabular}{|l|l|}
\hline $\begin{array}{l}\text { Радња може имати више токова и дигре- } \\
\text { сија }\end{array}$ & $\begin{array}{l}\text { Радња је усмерена на један низ и } \\
\text { тежи свом разрешењу }\end{array}$ \\
\hline Уопштен и формулативан стил & $\begin{array}{l}\text { Личан ауторски стил: неуоби- } \\
\text { чајена поређења, изражена ек- } \\
\text { спресивност, велико присуство } \\
\text { лирских елемената „Преко чи- } \\
\text { тавог неба, сва блистава, као ша- } \\
\text { рени лук, путовала је Мала река.” } \\
- \text { Небеска река) }\end{array}$ \\
\hline $\begin{array}{l}\text { Увек срећан крај - женидба јунака, ос- } \\
\text { вајање престола, поправљање штете }\end{array}$ & $\begin{array}{l}\text { Крај није нужно срећан, често } \\
\text { пунставља метаморфозу главне }\end{array}$ \\
\hline
\end{tabular}

Читањем и тумачењем ауторских бајки Гроздане Олујић на часовима српског језика и књижевности ученици развијају способност тумачења бајки и стрпљење у трагању за највишим смислом дела, упућују се на креативно изражавање, а развијају се и њихове способности језичког изражавања и критичког мишљења. Посматрањем одлика ауторских бајки Гроздане Олујић паралелно са одликама народне бајке ученици обнављају и проширују стечена теоријска знања из народне књижевности на конкретним, илустративним примерима, чинећи тако та знања дуготрајним. С друге стране својом лепотом, уметничким квалитетима и тематиком, ове бајке подстичу ученике на размишљање и буде љубав према читању и уметности уопште. Бајке Гроздане Олујић поручују да се треба борити и када нема великог изгледа на успех: „Бајка дарује управо то (највеће што се живоме створу, можда, може и дати!), дарује му поверење у самог себе, златне кључеве наде и поруку да никада ништа није изгубљено, нити за сва времена" (Олујић 1981), али исто тако упозоравају да се зарад остварења својих жеља и достизања лепоте често морамо нечег и одрећи. Пут одрицања и тежња ка достизању лепоте јесте оно што је карактеристично и за свако уметничко стварање. Уметност нам пружа утеху, наду и лепоту која је несвакидашња и драгоцена, али иза које стоји патња и бол, а то најбоље знају и разумеју ствараоци.

\section{ИЗВОРИ И ЛИТЕРАТУРА}

Бетелхајм 1979: Б. Бетелхајм, Значење бајки, Београд: Просвета.

Николић 2006: М. Николић, Методика наставе српског језика и књижевности, Београд: Завод за уџбенике и наставна средства. 
Мркаљ 2008: 3. Мркаљ, Наставно проучавање народних приповедака и предаға, Београд: Друштво за српски језик и књижевност Србије.

Мркаљ 2011: 3. Мркаљ, На часовима српског језика и књижевности, Београд: Завод за уџбенике

Олујић, Гроздана. Поетика бајке. http://documents.tips/documents/grozdanaolujic-poetika-bajke.html 13.01.2017.

Олујић 1979: Г. Олујић, Седефна ружа и друге бајке, Загреб: Младост.

Опачић 2011: 3. Опачић, Поетика бајке Гроздане Олујић, Београд: Српска књижевна задруга: Учитељски факултет.

Павловић 2008: М. Павловић, Припремање наставника и ученика за тумачење књижевних дела, Београд: Завод за уџбенике и наставна средства.

Пешикан Љуштановић, Љиљана. Усмена и ауторска бајка у настави. http://www.ff.uns.ac.rs/studenti/oglasne\%20table/oglasne_table_sr_knj/Bajka\%20od like\%20zanra\%20za\%20\%20nastavnike.pdf 16. 01. 2017.

Проп 2012: В. Проп, Морфологија бајке, Београд: Библиотека ХХ век.

\author{
Ana D. Kozić \\ LITERARY FAIRY TALES OF GROZDANA OLUJIĆ \\ IN THE TEACHING PROCESS
}

Summary

The paper researches the possibilities of interpretation of Grozdana Olujić's literary fairy tales in elementary school. Special emphasis is laid on the methodological techniques and procedures that are well motivated and harmonized with different aims in the teaching process. This paper also outlines the main differences between folk fairy tales and literary fairy tales using Grozdana Olujić's tales as an example.

Key words: Grozdana Olujić, literary fairy tale, folk fairy tale, teaching, interpretation, aims 